\title{
Equity and health of ethnic minorities
}

\author{
Ghada Karmi
}

The past decade in Britain has seen a growing literature on the health of ethnic minorities and their relationship with the health services. Two recent events have boosted this interest: the new contracting arrangements in the NHS, which require a more focused population approach, and the Chief Medical Officer's annual health report, just released, which devotes a specific chapter to ethnic minority health. ${ }^{1}$ Despite the amount and breadth of scope of what has been written on this theme significant lacunae of knowledge still remain, and this is as true now as when Johnson first noted the fact in the early $1980 \mathrm{s.}^{2}$ One of these gaps concerns the use of health services by ethnic groups, a subject which bears directly on the broader issues of equity and inequality. Though several studies have dealt with uptake of various services by ethnic groups (see below), these are a minority, and we have no comprehensive picture of how ethnic communities use the health service. As has been pointed out elsewhere, this is unquestionably the result of lack of routine ethnic monitoring within the service in Britain. ${ }^{3}$ Unlike the situation in the United States and some other countries, health statistics here are not routinely collected by ethnic group, and much of the British work on ethnicity and health has had to rely on local or ad hoc studies or to concentrate on specific conditions affecting ethnic groups, such as thalassaemia, sickle cell anaemia, or rickets. The only "ethnic data" routinely collected namely, death and birth statistics - derive from country of birth and cannot reflect the true picture as they automatically exclude ethnic people born in Britain. Until the 1991 census, which included an ethnicity question, the denominator statistics for ethnic populations in Britain existed only as country of birth of respondent or head of household. This dearth of information makes assessments of considerations of equity in ethnic groups a difficult undertaking.

\section{Definitions}

The concept of equity is not new in the health service. When the NHS was set up in 1948 it aimed at achieving equity in using and distributing resources, and this included equity of initial access to the health care system and equity in terms of quality and quantity of services received once access had been achieved. ${ }^{4}$ But we need to look more closely at what equity actually means. Is it equal treatment for equal need or for equal benefit? Who benefits, the individual or the community? Are some inequalities more acceptable than others (for example, discrimination against smokers or banning the use of kohl in Asian children)? In 1988 the National Association of Health Authorities (NAHA) defined equity in a multicultural society as a combination of several factors: that all people, irrespective of their religion, culture, race, colour, or ethnic background should have equal access to the NHS, should be offered services which are relevant and sensitive to their needs, should be able to use the NHS with confidence and expect to be treated with respect, should have equal rights of representation on NHS management bodies, and should have equality of opportunity in service provision and in NHS employment. ${ }^{5}$ There is no doubt that efforts to define and measure concepts such as equity or inequality bring into focus many basic issues which concern patients, health care workers, and policy makers.

It has been known for many years that both health status and provision of care vary widely in the community. These differences have traditionally been looked at in terms of social class, low income, and deprivation. A substantial class gradient in health was found by the Black report, ${ }^{6}$ based on data gathered in the 1960s and 1970s. The same findings were subsequently confirmed from data collected in the $1980 \mathrm{~s},{ }^{7}$ which also showed that housing tenure and employment status were associated with inequalities in health. Unemployment in particular has emerged as a leading cause of mental and physical ill health. ${ }^{8} 9$ Tudor Hart's "inverse care law" of equity in health, enunciated as far back as 1971 , referred to the fact that those in most need of health care receive the lowest proportion of health care resources. ${ }^{10}$ As a recent editorial in the $B M F$ stated: "the poor are likely to remain unhealthy so long as they remain poor; conversely, the way to improve their health is to improve their economic state." 11

\section{Ethnicity and poverty}

The role of ethnicity in the equation of ethnicity and poverty has frequently been suspected but never properly defined. Differences in mortality and morbidity have been repeatedly noted in immigrant groups. Studies of mortality have shown significant increases in deaths from cardiovascular disease, diabetes, and tuberculosis among South Asians and Afro-Caribbeans. ${ }^{12} 13$ Likewise, infant and perinatal mortality rates are strikingly higher for babies of mothers born in Pakistan, but they are also raised for babies of Bangladeshi and Caribbean mothers. Though the overall rates have been falling in these groups over the past decade they are still significantly raised. In 1990 the perinatal mortality rate for Pakistani mothers was highest of all groups, at 
$15 \cdot 6 / 1000$ live births, followed by that of $12 \cdot 5$ for Caribbean mothers. The rate in the United Kingdom for that year was $7 \cdot 8 .^{14}$ The important questions are how far this differential health experience derives from purely social factors and what contribution poverty, as opposed to ethnicity, makes. Two studies carried out in the early 1980 s tried to unravel the causes of the different perinatal mortality rates observed in ethnic mothers. Terry et al studied births at a Birmingham hospital in 1979 and concluded that the difference in perinatal mortality rates between ethnic minority and indigenous white groups was not related to social class. ${ }^{15}$ Gillies looked at all births and infant deaths occurring in Bradford and found large differences in mortality between Asian and United Kingdom babies, but these were independent of social class. ${ }^{16}$

Macintyre classifies the social causes of health into three categories: life circumstances, behaviours and beliefs or attitudes. ${ }^{3}$ A link between ethnicity and the first of these is easy to recognise since it is well known that ethnic communities tend to live in deprived inner city areas with poor housing, overcrowding, and lack of amenities. The Jarman underprivileged area score, which was based on ten social variables such as overcrowding and unemployment, also included ethnicity. ${ }^{17}$ The score showed a correlation between deprived areas and large percentage ethnic populations; seven of the ten most deprived health districts in England were found to be in London and were ethnic minority districts. Kushigemachi et al, on the basis of experience from research in the United States, drew attention to the fact that racial differences in acquiring tubercular infection may reflect environmental factors such as poverty and overcrowding rather than racial susceptibility. ${ }^{18}$ Unemployment rates in Britain are known to be higher among ethnic minority than among white groups. In 1990 the rate for Afro-Caribbean men was $13 \%$ and for Pakistani and Bangladeshi men was $15 \%$, compared with a rate of $7 \%$ for white men. ${ }^{19}$ Evidence of overcrowding is provided by the striking differences in room occupancy by ethnic group of the head of household in England. ${ }^{20}$ In $1988,10 \%$ of households with a non-white head were so crowded that they had less than one room per person. The differences were even more pronounced for Pakistani or Bangladeshi households, where the percentage with less than one room per person was $33 \%$. In her study of infant health in the east end Watson found that all the Bengali families in her sample lived in poor quality rented rooms, usually damp and in need of repair, and occupied by several generations of the same family living together. ${ }^{21}$ Kitchens and bathrooms were usually shared and hot water was rarely available. Three quarters of the Bengali mothers consulted for health problems in their babies by the age of 8 weeks, compared with $52 \%$ of indigenous mothers. She concluded that poor housing and environmental factors militated against good health for disadvantaged mothers and infants.
On the available evidence there is a plausible case for social and environmental causes of health inequality in ethnic groups. It is also likely that the health of ethnic groups is affected, not by one variable but as a consequence of the interaction of several factors - for example, being non-white, working in an unskilled occupation or being without a job, and living in dangerous and deprived parts of the inner city. But precisely how and in what measure ethnicity itself contributes to this composite picture, if at all, is difficult to assess from the available data. Evidence from the Charleston heart study showed that socioeconomic status was the key predictor for mortality from heart disease and not ethnicity. ${ }^{22}$ To resolve the problem we would probably need a monitoring process which assessed ethnic and socioeconomic groups together.

\section{Ethnicity and health inequality}

What is the evidence that ethnic groups do have a worse health experience than others in the United Kingdom? This question is easier to answer indirectly than directly. Many commentators have drawn attention to the unfavourable circumstances of ethnic minorities which could or should, in theory, lead them to have worse health. Baxter and Baxter, reviewing the literature on racial inequalities in health, found evidence to support the view that black people and people from ethnic minorities had a worse health experience than white people. ${ }^{23}$ They classified the evidence into three categories: the first relates to the unfavourable social factors described above; the second to the quality of health care available to deprived inner city areas where many ethnic communities live; and the third attempts to extrapolate the experience of health differences between black and white people in the United States to Britain. To this may be added other factors, frequently cited, which may have an indirect bearing on the health of ethnic minority groups: racial harassment from the community and racism in the NHS; inadequate training among health staff in multicultural health; inappropriate organisation of health services leading to poor uptake by ethnic groups; and reduced access because of language and unfamiliarity with British systems. The Commission for Racial Equality, quoting the London Interpreting Project in 1985, found that health authorities had been slow to recognise the need for interpreters and thereby jeopardised access of ethnic groups to the service. ${ }^{24}$ The NAHA report argued that access to ethnic minorities was reduced in several national health service areas: mental health, where there was a failure to understand the cultural context of psychiatric symptoms; disability, where black and ethnic people were doubly discriminated against; and diabetes, heart disease, and blood disorders, where the service on offer was deemed inappropriate and inaccessible. ${ }^{25}$

Direct evidence of a difference in mortality between ethnic groups has already been 
mentioned. In addition, several inherited diseases, such as sickle cell anaemia, thalassaemia, and G6PD deficiency, that occur in various groups have created further health differences. Some common diseases, such as diabetes, heart disease, and hypertension, for example, occur more commonly in some ethnic communities. Over and above this, various studies have also indicated differences in health experience for some ethnic groups. Blakemore found that elderly Asians and West Indians used general practitioner (GP) services more than elderly white people. ${ }^{26}$ Balarajan et al, reviewing data from the general household survey, found that in the age group 45 to 64 and after adjustment for socioeconomic class significantly higher rates of GP consultations were recorded for Pakistani, Indian, and West Indian people compared with their white counterparts. ${ }^{27}$ Likewise, Gillam et al reported significantly increased rates in London in male Asians, especially those consulting for upper respiratory tract infections and non-specific symptoms. ${ }^{28}$ A household survey of primary care services in the west Midlands also showed higher usage of GP facilities among Asians, but this was thought to be primarily related to poor socioeconomic status. ${ }^{29}$ Jackson et al, who analysed admission statistics in a Birmingham hospital, found ethnic differences in respiratory disease. ${ }^{30}$ Asthma and respiratory tuberculosis were much commoner in Asians, but, on the other hand, in West Indians the occurrence of carcinoma of the bronchus and of bronchitis was low. Patterns of cigarette smoking could not account for these differences. There are also differences in the prevalence of psychiatric illness. Admission rates to psychiatric hospitals are above average in Afro-Caribbeans and the rate for schizophrenia is three to five times that for white people. The children of Afro-Caribbean immigrants have even higher rates of schizophrenia, from seven to thirteen times more than white people. ${ }^{31}$ These striking differences have led to a debate over the role of misdiagnosis and racism in treating AfroCaribbean patients with psychiatric problems. However, the admission rates for psychiatric treatment in Asian immigrants seem to be low, a finding which has led to the suspicion of underdiagnosis and under-recognition of mental illness in this group rather than a genuinely lower prevalence in psychiatric morbidity. ${ }^{32}$

\section{Equity and ethnicity}

There is evidence to support the view that ethnic minorities do indeed have a different health experience from the indigenous majority in Britain. What is less clear is how much is related to issues of equity. As we have seen, a theoretical case can certainly be made for how and why discrimination and ignorance in British systems and in society at large can lead to ill health in ethnic minorities, but actual evidence is scarce. However, a few studies have provided suggestive evidence. For example, Cummins et al, in a study of penicillin prophylaxis in children with sickle cell disease, found that local GPs' knowledge of sickle cell disease and the need for penicillin prophylaxis was generally poor. ${ }^{32}$ Donaldson's survey of elderly Asians in Leicester showed that only a few were aware of social services, and they were in any case hampered by language difficulties: $37 \%$ of the men and only $2 \%$ of the women knew any English. ${ }^{34}$ In a community study in west London, Asian women were commonly unware of the existence or importance of cervical screening. ${ }^{35}$ By extrapolation from Stefenson and Colker's study of intercultural misunderstanding in Australia it is possible to see how successful health care delivery can be hampered by the lack of a shared culture between doctor and patient. ${ }^{36}$

Though these findings are suggestive, none of the research in Britain has been able to show any ill effects to patients directly as a result of any of these factors. Gillam, in a wide ranging paper, could find little more than anecdotal evidence to support the contention that the health of ethnic minority groups was poorer than that of the population at large or that ethnic minorities were underusers of the health service. ${ }^{37}$ Similarly, the role of racism in causing ill health and reduced access for ethnic groups remains plausible but is difficult to quantify. Recognising this in his discussion on the generation of mental illness among black people in Britain, Burke nevertheless considered that racism was a causative factor because it was so socially pervasive ${ }^{38}$ Even so, we do lack the sort of evidence which is available in the United States, ${ }^{39}$ where, for example, it has been found that black psychiatric patients are less likely to receive a broad range of treatments on offer to their white counterparts. ${ }^{40}$ Another American study showed that black patients with pneumonia received fewer hospital services than white patients with the same diagnosis ${ }^{41}$; likewise, black patients in the United States who needed surgery were twice as likely as white patients to be treated by surgeons in training, whether for elective or emergency surgery. ${ }^{42}$

Without better evidence assessments of the causes for different health in ethnic groups in Britain must remain hypothetical. The current British literature on ethnicity and health which abounds with opinion, speculation, and even passion is no substitute for factual evidence. Though a proper programme of research is needed to clear up some of the ambiguities, it will not be sufficient on its own. What is required is a whole new approach to the concept of "ethnic minorities." As long as this meaningless label continues to be used, implying as it does a commonality of definition and experience between groups as diverse as Greeks and Sri Lankans, the confusion about ethnicity and health will persist. It is high time that people were regarded as belonging to their individual communities, whether they be English or Indian or Italian. Only then can the right questions be asked, can the answers be properly assessed, and can the solutions, if any, to inequity in health be found. 
1 Calman $\mathrm{K}$. The health of black and ethnic minorities. In: On the state of the public health. London: HMSO, 1991: On the

2 Johnson MRD. Ethnic minorities and health. $\mathcal{f} R$ Coll Phys Lond 1984;18:228-230.

3 Macintyre $S$. The patterning of health by social position in contemporary Britain: directions for sociological research. Soc Sci Med 1986;23:393-415.

4 Collins E, Klein R. Equity and the NHS: self reported morbidity, access and primary care. BMF 1980;281: 1111-5.

5 National Association of Health Authorities. Action not words. London: NAHA, 1988:12.

6 Townsend P, Davidson N. Inequalities in health: the Black report. Harmondsworth: Penguin, 1982.

7 Whitehead M. The health divide: inequalities in health in the 1980s. London: Health Education Council, 1987.

8 Moser KA, Fox AJ, Jones DR. Unemployment and Moser KA, Fox AJ, Jones DR. Unemployment and
mortality in the OPCS longitudinal study. Lancet 1984; mortality in the OPCS longitudinal study. Lancet 1984;

9 Stern J. The relationship between unemployment, morbidity and mortality in Britain. Population Studies 1983;37:61.

10 Tudor Hart J. The inverse care law. Lancet 1971;i:405.

11 Smith T. Poverty and health in the 1990s. BMF 1990;301 349-50.

12 Marmot MG, Adelstein AM, Bulusu L. Lessons from the study of immigrant mortality. Lancet 1984;i:1455-7.

13 Balarajan R, Adelstein AM, Bulusu L,Shukla V. Patterns of mortality among migrants to England and Wales from the Indian subcontinent. BMF 1984;289:1185-7.

14 OPCS. Mortality statistics, perinatal and infant: country of birth. London: HMSO, 1990:18. (Series DH3, No 24.)

15 Terry PB, Condie RG, Settatree RS. Analysis of ethnic differences in perinatal statistics. BMF 1980;281:
dict PB, Condie RG, Settatree RS. Analysis of ethnic differences

16 Gillies DRN. Analysis of ethnic differences in stillbirths. f Epidemiol Community Health 1984;38:214-7.

17 Jarman B. Identification of underprivileged areas. $B M \mathcal{F}$ 1983;286:1705-9.

18 Kushigemachi $M$, Schniederman LJ, Barrett-Connor E. Racial differences in susceptibility to tuberculosis: risk of disease after infection. Fournal of Chronic Diseases 1984; 37:853-62.

19 Central Statistical Office. Social trends. London: HMSO, 1992:82-3.

20 Central Statistical Office. Social trends. London: HMSO, 1992:149.

21 Watson E. Health of infants and use of health services by mothers of different ethnic groups in east London. mothers of different ethnic grol

22 Keil JE, Sutherland SE, Knapp RG, Tyroler HA. Does equal socioeconomic status in black and white men equa risk of mortality? Am f Public Health 1992;82:1133-6.

23 Baxter C, Baxter D. Racial inequalities in health: challenge to the British National Health Service. In
Towards quality and equality. Bradford: Bradford Hospitals NHS Trust, 1988:4-11. (Reproduced from International fournal of Health Services, 1988;18.)

24 Commission for Racial Equality. Race relations code of practice in primary health care services. London: CRE, 1992:34-8.

25 National Association of Health Authorities. Action not words. London: NAHA, 1988:8-11.

26 Blakemore K. Ethnicity, self-reported illness and use of medical services by the elderly. Postgrad Med f 1983;59: 668-70.

27 Balarajan R, Yuen P, Soni Raleigh V. Ethnic differences in general practitioner consultations. BMF 1989;299: 958-60.

28 Gillam SJ, Jarman B, Law R. Ethnic differences in consultation rates in urban general practice. $B M 71989$ 299:953-7.

29 Johnson MRD, Cross M, Cardew SA. Inter-city residents, ethnic minorities and primary health care. Postgrad Med f 1983;59:664-7.

30 Jackson SHD, Bannan LT, Beevers DG. Ethnic difference in respiratory disease. Postgrad Med f 1981;57:777-8.

31 Littlewood R, Lipsedge M. Psychiatric illness among British Afro-Caribbeans. BMF 1988;296:950-1.

32 Brewin C. Explaining the lower rates of psychiatric treatment among Asian immigrants to the United Kingdom: a preliminary study. Social Psychiatry 1980;15: $17-9$

33 Cummins D, Heuschkel R, Davies SC. Penicillin prophylaxis in children with sickle cell disease in Brent. $B M \mathcal{F}$ 1991;302:989-90.

34 Donaldson LJ. Health and social status of elderly Asians: community survey. BMF 1986;293:1079-82.

35 Doyle Y. A survey of the cervical screening service in a London district, including reasons for non-attendance, London district, including reasons for non-attendance, ethnic responses and views on

36 Stefensen MS, Coker L. Intercultural misunderstandings about health care. Soc Sci Med 1982;16:1949-54

37 Gillam S. Ethnicity and the use of health services. Postgrad Med $\mathcal{f}$ 1990;66:989-93.

38 Burke AW. Racism and psychological disturbance among West Indians in Britain. Int $\mathcal{F}$ Soc Psychiatry 1984;30 $50-68$.

39 Manton KG, Patrick CH, Johnson KW. Health differentials between blacks and whites: recent trends in mortality and morbidity. Milbank $O$ 1987;65(suppl 1):129-99.

40 Littlewood $R$, Cross S. Ethnic minorities and psychiatric services. Sociology of Health and Illness 1980;2: atric service.

41 Yergan J, Flood AB, LoGerfo JP, Diehr P. Relationship between patient race and the intensity of hospital between patient race and the inter

42 Egbert LD, Rothman IL. Relation between the race and economic status of patients and who performs their surgery. N Engl f Med 1977;297:90-1. 